\title{
Misión náutica. De libros, discursos y prácticas culturales en la Carrera de Indias de los siglos XVI y XVII*
}

\author{
Carlos Alberto GonzÁlez SÁnchez \\ Universidad de Sevilla \\ calberto@us.es
}

Fecha de recepción: 22/11/2012

Fecha de aceptación: 02/07/2013

\begin{abstract}
RESUMEN
Este artículo pretende una reflexión sobre la importancia de la cultura escrita en los viajes transoceánicos de los siglos XVI y XVII, sobre todo los que se realizaban entre España y sus colonias americanas; pero sin dejar de lado los de la metrópoli portuguesa. De esta manera, el objetivo principal del trabajo gira en torno al papel que desempeñó el discurso religioso durante las travesías de los océanos, trayectos peligrosos que los clérigos que solían viajar en los barcos, muchos de ellos rumbo a las misiones de los nuevos mundos, aprovechaban para la instrucción religiosa de los viajeros y tripulantes que encontraban a bordo.
\end{abstract}

Palabras clave: viajes oceánicos, cultura escrita, clero, religiosidad, misiones.

\section{Nautical mission: on books, discourses and cultural practices in the Carrera de Indias during the sixteenth and seventeenth centuries}

\begin{abstract}
This article considers the significance of written culture on the transoceanic voyages of the sixteenth and seventeenth centuries, focusing mainly on travels between Spain and its American colonies, but also on Portuguese navigations. The article's main goal is to establish the role played by religious discourses during the overseas journeys. The ships normally carried numerous clergymen who took advantage of dangerous circumstances during the trip in order to indoctrinate travellers and crews.
\end{abstract}

Key words: overseas voyages, writing culture, clergy, religiosity, missions

\footnotetext{
* Este trabajo se inscribe dentro del Proyecto I+D+I Inquisición, cultura y vida cotidiana en el Mundo Hispánico (siglos XVI-XVIII), ref. HAR2011-27021, del Ministerio de Economía y Competitividad.
} 


\section{ASÍ EN EL MAR COMO EN EL CIELO}

A la vista de los testimonios escritos de viajeros por los nuevos mundos de la alta Modernidad (cartas, memoriales, relaciones, informes, registros de navíos), no resulta complejo especular sobre los objetos gráficos con los que se pertrecharon para aquellos periplos a la ventura. Entre ellos el libro, manuscrito o impreso, antes de llegar a las tierras de destino cumplía una función primordial en las travesías oceánicas que lo llevaban hasta la meta deseada ${ }^{1}$. Más de cien días de navegación a merced de los infernales caprichos de la naturaleza y de la vesania humana, en unos navíos, poco mayores que barcas de remos, con un espacio vital reducido al mínimo y un avituallamiento siempre al borde de la extinción, leer, como adujera Fr. Antonio de Guevara en 1539 , era el pasatiempo más oportuno y pacífico ${ }^{2}$.

Las adversidades y peligros propios de la navegación de entonces (naufragios, tempestades, corsarios y piratas, guerras, escasez de agua y alimentos, pésimas condiciones higiénicas), unido a la inadaptación al medio, en unas jornadas interminables, de los ajenos a la profesión del mar, exasperaban los ánimos y predisponían toda suerte de angustias y violencias. Tal cúmulo de circunstancias poco gratas, inciertas y al acecho de la muerte, auspiciaban las llamadas a la intercesión celestial. Estos ruegos al más allá se efectuaban a través de la oración, y, a menudo, sustentados en escritos de contenido religioso (biblias, diurnos, horas, breviarios, misales, estampas de santos y textos piadosos) capaces de ahuyentar la ira divina, de procurar el perdón de los pecados y, en avatares extremos, el sosiego eterno en la otra vida, pues la terrena no siempre estaba acorde a la fe profesada. No obstante, dichos productos gráficos también podían ser un entretenimiento ideal durante una agónica aventura que, según los moralistas de la época, se debía aprovechar para reflexionar y cimentar conductas y virtudes cristianas con las que lograr la reconciliación con Dios.

Fr. Antonio de Guevara (1480-1545), egregio polígrafo del siglo XVI, dio un saludable consejo, para superar tormentos y aminorar el trayecto, a los pasajeros de cualquier embarcación, en especial a los que presumen de cuerdos y honrados; es como sigue: "compre algunos libros sabrosos y unas horas devotas; porque de tres ejercicios que hay en la mar, es a saber, el jugar, el parlar y el leer, el más provechoso y menos dañoso es el leer"'. Al igual, el general Juan Escalante de Mendoza (15291596), culto y diestro mareante de la Carrera de Indias del Quinientos, recomienda a las gentes de mar doblegar el tedio con libros devotos y de sabios autores:

Mas con todo me parece que será bien advertir y aconsejar a todo buen marinero que demás de los libros de su arte, siempre traiga consigo otros de buena doctrina y sabios autores, y que el tiempo que hubiere de estar ocioso, o jugando, lo emplee y ocupe

\footnotetext{
1 Una novedad editorial al respecto es la de Algranti, L. M. y Megiani, A. P. (orgs.): O Império por Escrito. Formas de transmissão da cultura letrada no Mundo Ibérico (séc. XVI-XIX), São Paulo, Alameda Editorial, 2009.

2 GuevarA, A. DE: De los muchos trabajos que se pasan en las galeras, Valladolid, 1539. Lo recoge en un apéndice Martínez, J. L.: Pasajeros a Indias. Viajes transatlánticos en el siglo XVI, México, Fondo de Cultura Económica, 1999, pp. 231-251.

3 Guevara, op. cit. (nota 2).
} 
en leer y estudiar en ellos, porque haciéndolo así y con el uso y discreta experiencia vendrá a saber mucho ${ }^{4}$.

Hemos de considerar, no obstante, que el libro piadoso, en una sociedad sacralizada y mayoritariamente analfabeta, podía cumplir otras funciones distintas a la de su lectura en situaciones diversas, ya fuere silenciosa, en voz alta, colectiva o individual. Entre estas utilidades alternativas primaría la de símbolos u objetos de culto, fetiches o talismanes cuya naturaleza sagrada los convierte en mediadores sobrenaturales. De este modo, la simple posesión podía garantizar protección frente a circunstancias adversas y asegurar un potencial mirífico a unos fieles necesitados de esperanzas y satisfacciones espirituales. La reducción del tamaño que desde mediados del siglo XVI van experimentando estas manufacturas tipográficas, hasta formatos, en $8^{\circ}$ y $16^{\circ}$, fácilmente transportables - de bolsillo diríamos hoy- $\mathrm{y}$, gracias a su multiplicación mecánica más baratos, evidencia, además del éxito editorial, una interesante diversidad de usos. Debieron ser muchas las personas que se protegían de enemigos mortales e invisibles con unas horas u otro devocionario que jamás leían o que ponían entre sus manos cuando rezaban en cualquier lugar oportuno ${ }^{5}$. Las estampas que por lo común suelen ilustrarlos pueden ser otro de los móviles fundamentales de su posesión. He aquí el consejo de un denodado asceta de la época, el jesuita Nicolás de Arnaya (1557-1623), misionero y provincial de su orden en México:

que en ellos como en unas armerias, se pueden armar todos los fieles para defenderse de sus enemigos y hazerles la guerra. Esta el ayre lleno de saetas, y dardos arrojadizos, con que pretenden atravesarnos el coraçon nuestros enemigos, y assi conviene armarnos con divinas letras. ${ }^{6}$

Los recursos del rezo y la lectura religiosa son manifiestos, como era de esperar entre clérigos regulares, en el relato que el dominico fray Tomás de la Torre $(+1567)$ escribió del accidentado viaje que hizo de Sevilla a Tabasco (México) con Bartolomé de las Casas y otros correligionarios en 1544. Cuenta de su grupo que

en estando para ello comenzamos a entrar en concierto y comíamos juntos con lección y decíamos cada día misa en secreto, y los domingos y fiestas las cantábamos y había sermón a todo el navío, y cada noche cantábamos la salve ${ }^{7}$.

4 Escalante de Mendoza, J.: Itinerario de navegación de los mares y tierras occidentales 1575, edición de R. Barreiro-Meiro, Madrid, Museo Naval, 1985, p. 116.

5 De Álvarez Santaló, L. C.: "Religiosidad moderna y cultura lectora en la España de los siglos XVI al XVIII”, en Cortés, A. L. y López-Guadalupe, M. (dirs.): Estudios sobre Iglesia y sociedad en la Andalucía moderna, Granada, Universidad de Granada, 1999, pp. 225-265. Muy útil también: Pérez GARCíA, R. M.: Sociedad y lectura espiritual en la Castilla del Renacimiento, 1470-1560, Madrid, Fundación Universitaria Española, 2005; y PALOMO, F.: "Cultura religiosa, comunicación y escritura en el Mundo Ibérico de la Edad Moderna”, en Serrano, E. (coord.): De la tierra al cielo. Líneas recientes de investigación en Historia Moderna, Zaragoza, Institución “Fernando el Católico"-Universidad de Zaragoza, 2013, pp. 53-88.

6 Arnaya, N.: Conferencias espirituales, utiles, y provechosas para todo genero y estado de personas, Sevilla, Francisco de Lyra, 1617, p. 157.

7 El diario del viaje de Fr. Tomás de la Torre también lo reproduce completo José L. Martínez en el apéndice de Pasajeros de Indias, op. cit. (nota 2), pp. 252-293. 
Pero tras describir con todo lujo de detalles el sinfín de penalidades que les tocó experimentar a bordo -vértigos, tormentas, hambre, sed, enfermedades, muertes, agresiones-, narra cómo los más hacían frente a la pesadilla atlántica:

unas veces llorando y otras cantando el rosario, salmos e himnos, aquí tres, acullá seis. Los seglares tañendo guitarra y cantando romances, y cada uno a su modo: visitábamos Nuestro Señor con gran consolación y muchos se iban en un rincón en oración, otros leyendo en libros, y hartos llorando arroyos de lágrimas 8 .

La mayoría de los habitantes del barco, por tanto, se enajenaba de aquellos maléficos días de la manera que el medio y el miedo permitían: llorando, leyendo, cantando. Si bien, no serían muchos, aparte de los frailes y algún que otro individuo adiestrado en letras, los que podían evadirse de tantas semanas aciagas mediante la lectura individual y silenciosa, y en la medida de lo posible solitaria, que Fr. Tomás nos refiere; una técnica en continuo progreso desde la Edad Media que anulaba la separación entre el mundo del texto y el del lector, y con la que el escrito ganaba una notoria y desconocida fuerza imaginativa y de persuasión, considerada por la Iglesia especialmente peligrosa y nociva en las deshonestas ficciones y otros cuentos de invención poética que tanto encantaban y maravillaban al público de naos y galeones. No obstante, los componentes de la cultura oral que se mencionan, canciones y romances, y la lectura colectiva en voz alta, habitual entonces, suplirían las carencias alfabéticas del grueso de pasajeros y tripulantes ${ }^{9}$. Al menos así lo exhibe el acta inquisitorial de una visita, en busca de libros prohibidos, efectuada en el navío Santa María de Arratia en el puerto de San Juan de Ulúa en septiembre de 1582, en la que un declarante afirmó que "el pasajero Alonso Almaraz estaba un día leyendo la vida de San Luis y desde entonces hacían que les leyera"10.

Idénticas recomendaciones argumentó Pedro Fernández de Quirós (1565-1614) a sus marineros a la zaga de la quarta pars incognita, Australia. En una ocasión, intentando disuadirles de matar el tiempo jugando a dados y naipes, divertimentos prohibidos en las instrucciones oficiales dadas a la expedición, y mediando en el altercado subsecuente que se produjo, pero consciente del desaliento que provocaban unas tentativas descubridoras frustrantes y prolongadas en demasía, les ofreció como alternativa una honrosa ocupación: "para gasto de tiempo tenía muy buenos libros, quien enseñase a leer, escribir y contar a los que no sabían... y que esto les convenía más que jugar su dinero" ${ }^{11}$. Tampoco faltan en su relación testimonios de lectura común

\footnotetext{
8 Ibidem.

9 Sobre este tema Chartier, R.: Las revoluciones de la cultura escrita, Barcelona, Gedisa, 2000; y BouZA, F.: Del escribano a la biblioteca. La civilización escrita europea en la Alta Edad Moderna (siglos XV-XVII), Madrid, Síntesis, 1992.

10 En Fernández del Castillo, F.: Libros y libreros en el siglo XVI, México, Fondo de Cultura Económica, 1982, p. 389. Este libro es una recopilación de documentos de la Inquisición de México, entre los que se encuentra un interesante conjunto de actas de visitas de naos llegadas al puerto de Veracruz. Para la lectura en voz alta: Chartier, R.: "Loisir et sociabilité: lire à haute voix dans 1'Europe moderne", Littératures Clasiques, 12, 1990, pp. 127-147. También Frenk, M.: Entre la voz y el silencio. La lectura en tiempos de Cervantes, Alcalá de Henares, Centro de Estudios Cervantinos, 1997.

11 Fernández de Quirós, P.: Descubrimiento de las regiones australes, edición de R. Ferrando, Madrid, Historia 16, 1986, p. 236.
} 
y oral. Fracasada su onírica empresa austral, navegando de vuelta a Nueva España, menciona una mañana en la que "habían estado muy atentos oyendo leer la vida de San Antón ermitaño, y que alabándola mucho dobló la hoja y guardó el libro" ${ }^{12}$. Tanto encendió la piedad de sus hombres que uno de ellos se arrojó en una tabla al mar con la intención de volver a las tierras dejadas atrás para evangelizar a sus naturales.

Podemos seguir esta secuencia de representaciones con el misionero jesuita Hernando de Padilla (1550-1607). En el diario de su viaje a Lima (1628-29), en compañía de otros de su religión, menciona cómo empleaban el escueto tiempo de sosiego en el navío, del modo siguiente: "quando las ocupaciones, o la salud lo permitían se recogian en sus exercicios espirituales, de oracion, examenes, licion espiritual y rosario" ${ }^{13}$. Este ejercicio de oración interior, un ritual con unos pasos bien definidos que promovió la Compañía de Jesús y la Contrarreforma, concibe la lectura como una práctica ascético-espiritual individual y silenciosa sin otro mediador entre Dios y el creyente que un libro, el soporte de la meditación que, una vez cumplida su función -proporcionar el argumento meditativo-, debía ser desechado. La oración introspectiva, pues, siempre trasciende al texto que le antecede ${ }^{14}$. El franciscano Diego de Estella (1524-1578), uno de los ascetas más famosos de aquel tiempo, así lo estipula con pocas palabras: "Has de sacar de la lección el affecto de la devoción, y formar desde allí la oración, dejando la lección" ${ }^{15}$.

El método, ajustado a la composición de lugar ignaciana, y para evitar las veleidades de la libre imaginación mística, consistía en meditar en lo concreto y no en lo abstracto, o lo que es lo mismo, la representación mental, dentro de unos cauces estrictamente definidos y en un contexto físico concreto, de la humanidad de Cristo o las postrimerías del hombre, fórmula que se desarrolla a través de motivos efectistas, emotivos, sensoriales y visuales. El fin no es otro que golpear los sentidos del creyente para dirigirle su religiosidad, y su vida en general, y provocarle así las conductas y reacciones emotivas deseadas: arrepentimiento, compasión, humildad, caridad, miedo, obediencia, paciencia, piedad o satisfacción ${ }^{16}$.

La lección espiritual, colectiva e individual, también fue el pasatiempo obligado y habitual durante la travesía oceánica de los evangelizadores que, en 1612, llevó al

12 Fernández de Quirós, P.: Memoriales de las Indias Australes, edición de Óscar Pinochet, Madrid, Historia 16, 1991, p. 294.

13 Se trata del manuscrito hológrafo Relación del viaje del padre Hernando de Padilla y sus compañeros a Lyma de 1628 y de 1629, Real Academia de la Historia (RAH), Papeles de Jesuitas, t. CXXIX, fols. 555 y ss. Debo agradecer su consulta a Delphine Tèmpere, quien además es autora de un excelente libro, de referencia para las cuestiones que aquí se tratan: Vivre et mourir sur les navires du siècle D'Or, París, Presses de 1'Université Paris-Sorbonne, 2009. Asimismo, CAstillo Gómez, A.: "Leer en comunidad. Libro y espiritualidad en la España del Barroco", Via Spiritus, 7 (2000), pp. 99-122; ID.: Leggere nella Spagna moderna. Erudizione, religiosità e svago, Bolonia, Pàtron Editore, 2013.

14 Aquí recomiendo en excelente ensayo de Bouza, F.: "Leer para creer. Religión y cultura del libro en la Edad Moderna", en Cortés Peña, A. L. (coord.): Historia del cristianismo, Madrid, Trotta, 2004, pp. 637-680.

15 Estella, D. DE: Libro de la vanidad del mundo, Alcalá de Henares, Juan Gracián, 1597, p. 96.

16 Uno de los grandes estudiosos de la lectura ascético-espiritual fue Orozco, E.: Manierismo y Barroco, Madrid, Cátedra, 1981. Un estado de la cuestión recojo en mi trabajo "Lection espiritual. Lectores y lectura en los libros ascético-espirituales de la Contrarreforma”, en González SÁncheZ, C. A. y Vila Vilar, E. (comps.): Grafias del imaginario. Representaciones culturales en España y América (siglos XVI-XVIII), México, Fondo de Cultura Económica, 2003, pp. 272-300. 
Perú Jerónimo Pallas (1594-1670), otro jesuita que pensaba no haber mejor manera de combatir la herejía y defender la Iglesia sino mediante sermones, pláticas, disputas y libros impresos ${ }^{17}$. Como otros muchos evangelizadores aprovecharon el tiempo oyendo las lecturas en quechua que les hacía el padre Juan Vázquez, uno, entre otros, de los ejercicios en el aprendizaje de la lengua con la que habrían de trabajar en el lugar de destino ${ }^{18}$.

\section{PURGATORIO FLOTANTE}

Lo prolongado de la travesía y el angosto y rutinario espacio vital de los navíos, unido al hastío y la desocupación que ambos factores provocaban en pasajeros y tripulantes, daban aliento y ponían en suerte, en el tiempo libre, los deberes pastorales y las ansias misionales de los religiosos que por lo común viajaban a bordo. No se apearon de esta función -que de paso hacía menos melancólico el dilatado cruce del Océano-cuantos principiantes jesuitas deseosos de fortalecer el celo y la vocación, la obediencia y la voluntad, a través de vivencias y maravillas en los universos alejados y exóticos a los que, con fervor militante, iban a probar el martirio por la fe. En estas cuitas náuticas Hernando de Padilla y sus correligionarios emplearon muchas horas en el barco, enseñando la doctrina a una humanidad flotante, tratando, "en racionamientos siculares", asuntos tocantes al aprovechamiento del alma capaces, cual era su meta, de predisponer en muchos la confesión de los pecados. El resultado fue óptimo: 190 personas confesaron y comulgaron en la nao capitana. Tampoco faltaban prédicas y sermones en reclamo de arrepentimientos y delineando las actitudes arquetípicas del buen cristiano, entre las que elevaron el abandono de los libros profanos y de comedias, que harto había en los buques, por los de devotas y sanas enseñanzas. Desde entonces, y a causa de tan encendida exhortación ascética, cuenta el jesuita, no hubo hombre de mar ni pasajero que en aras de paz interior dejara de

buscar, y hallados leer en libros pios como de confesonarios, catesismos y guias de pecadores y otros deste jaez, sin que apenas se oyese en todo el galeon un juramento una palabra deshonesta, que negros ignorantes aun de persignarse sabian ya muy bien oraciones o lo que habian oido al padre en la platica, efectos todos estos ${ }^{19}$.

En esta misión acuática, conforme al programa y la maña de los ignacianos, las imágenes sagradas también contribuyeron a la conversión de confiados y perdidos. El día de san Francisco Javier, en el centro del navío se asentó sobre un dosel una estampa grande del santo, guarnecida con un marco plateado, con el fin de sacralizar

17 Mission a las Indias, con advertencias para religiosos de Europa que la huvieren de emprender, como primero se verá en la historia de un viage y después em discurso. Al muy $R^{\circ} P e$ Geronymo Pallas de la misma Compañía. Archivum Romanum Societatis Iesu (ARSI), Provincia Peruana 22, p. 79.

18 De suma utilidad: Romano, A.: "El libro como instrumento de la construcción de un mundo global: los misioneros y la cultura del escrito", EREBEA, 2, 2012, pp. 109-126; y PALOMo, F., "Anaqueles de sacra erudición: libros y lecturas de un predicador en el Portugal de mediados del siglo XVII", Lusitânia Sacra, 18 (2006), pp. 117-146.

19 RAH, Papeles de jesuitas, t. CXXIX, doc cit. (nota 13). 
el espacio y, a la vez, para que se venerase y honrase la abnegada entrega misional y memoria ejemplar de aquel adalid cristiano ${ }^{20}$. La palabra, el libro y otros productos gráficos icónico-visuales, todos en sabia y cuidada combinación doctrinaria, libraron a muchas almas necesitadas de las garras del demonio y de sus tiránicas prisiones, de las torpezas y aficiones inicuas que las abrasaban en el fuego de una ira rabiosa. Los padres de la Compañía, aparte, cumplían un plan de vida estricto y riguroso. Cada mañana asistían a misa; después acometían estudio quieto y las reflexiones sobre lo estudiado. La comida la hacían sin que

a la mesa faltase lecion de un libro devoto, que para este sustento se escojio un tratado no menos erudito que uno hecho por el padre Alonso de Sandoval de instauranda aethiopum salute, particularmente el tercer libro que trata de los misterios de esta jente instruiendo con documentos practicos a nuestros obreros en el modo que con semejantes han de guardar para su catesismo baptismos ${ }^{21}$.

Concluida tan provechosa, anímica y corporal pitanza, se recogían en descanso para, más tarde, volver al estudio y a la lección espiritual hasta la noche, momento en el que saltaban a cubierta cantando la salve y rezando avemarías. El buque, en suma, fue un espacio idóneo para poner en experimento los métodos misionales que iban a desarrollar al otro lado del Atlántico. Un eficaz auxilio les prestaría el manual del padre Alonso Sandoval (1576-1652), una acertada guía práctica resultado de su pericia evangelizadora con indios y esclavos etíopes del Perú, que puso a buen recaudo la llama vocacional de aquellos jesuitas, en especial la de los neófitos, durante la navegación con destino a la tierra incaica. La intención, a la vista de los resultados y de la subjetiva representación de Padilla, fue buena y fructífera. El espíritu de los misioneros quedó gratamente compensado.

De esta manera los barcos, auténticos microcosmos, de buenas a primeras, y al provecho de acontecimientos con riesgo fortuitos -tempestades y ataques de corsarios o piratas-, se transformaban en espacios sagrados durante todo el viaje, cuasi templos flotantes e intercesores celestiales. La misión, pues, comienza en el mar y no en las nuevas tierras; a bordo iban, empleando la terminología de los jesuitas, los "otros indios", muchas veces peores cristianos que los caribes. En particular, el común de los mareantes, una profesión, en su escalafón inferior ante todo, en la época vista como producto de la suma pobreza y la desesperación, artífice de una empresa incierta y espantosa que siempre conlleva una mala vida, cruel y perversa, aliada de una muerte constante. Unos hombres, como fuere, denostados por malquistos y, lo

20 Imprescindible resulta Gruzinski, S.: La guerra de las imágenes. De Cristóbal Colón a Blade Runner (1492-2019), México, Fondo de Cultura Económica, 1994. Del mismo autor, su gran obra: Les Quatre parties du monde. Histoire d'une mondialisation, París, Éditions de la Martinière, 2004.

21 Se trata del libro del misionero sevillano Alonso de Sandoval, De Instauranda Aethiopum Salute. Nicolás Antonio cita una edición madrileña, en folio, de 1646. Pudo haber una anterior o estaban usando un manuscrito. Sandoval fue un experto misionero que estuvo en Lima con indios y esclavos negros. Murió en 1652 . 
peor, por ignorantes del credo cristiano, blasfemos, presa de la superstición, cuasi paganos, y sin temor de un Dios del que sólo se acuerdan cuando el peligro acecha ${ }^{22}$.

No había mejor modo, por tanto, de curar los síntomas del aburrimiento que lograr bien el tiempo y no malograrlo en ociosidad, madre de vicios, madrastra de la virtud, raíz, fuente y origen de mil males que se evitan con el honesto trabajo. Ya el agustino Tomás de Kempis (1380-1471), gran místico del Medioevo y uno de los autores religiosos más leído entonces, y hasta hoy, decía:

Bueno es que algunas veces nos vengan cosas contrarias: porque muchas veces atraen el hombre al corazón, para que se conozca desterrado y no ponga su esperanza en cosas del mundo...esto ayuda a la humildad y nos defiende de la vanagloria...entonces conoce tener de Dios mayor necesidad, pues que ve claramente que sin él no puede nada bueno ${ }^{23}$.

Presto lo siguió el doctor y racionero de la catedral de Lima Diego Portichuelo de Rivadeneira, que, al contrario de casi todos nuestros navegantes-escritores, relata su viaje invirtiendo la dirección, del Callao a España en 1654. Las envestidas del océano y el torrente de adversidades que hubieron de enfrentar las gentes de su nao, le dieron el mejor pretexto posible y oportunidad para poner a prueba su astucia misional con las personas de a bordo, a las que hizo ver que la furia del mar, crisálida del infierno, era la más evidente manifestación de la ira divina frente al pecado y el desprecio de la piedad de los embarcados. El clérigo, claro está, se lucró del recuerdo de santa Bárbara cuando truena, es decir, hizo ver que una vida virtuosa y cristiana, en permanente estado de alerta y no sólo ante situaciones extremas, era la norma aconsejable en tormentos como los vividos, y la más eficiente en la obtención de misericordias. Por ello, como pudo y ayudado de otros religiosos que iban en el barco, el racionero se dedicó, sólo con la palabra, a disciplinar y doctrinar a pasajeros y tripulantes, quienes se mostraron humildes y sumisos a la resolución de conflictos entre ellos, el arrepentimiento, la confesión, la comunión y la penitencia. Pero Portichuelo echó de menos un útil fundamental en la acción misional emprendida; así lo anotó en su relación:

Y viendo el fruto que se conseguía, proseguí con la predicación, como lo hice todo el viaje, los miércoles y los viernes, y como yo no tenía allí libros, y a esta falta se seguía mi insuficiencia. Y bien se conoció que allí andaba el dedo de Dios, pues lo que Su Majestad obró en aquella gente, que serían de 350 hombres, y las penitencias que hicieron fueron tales, que parece que en todo era el navío otra Nínive convertida ${ }^{24}$.

El cumplimiento con los deberes religiosos durante la travesía era una obligación que todo buen fiel debía observar, y el capitán del navío asegurar. En las naos, como

22 Sobre este imaginario son fundamentales los libros de PéRez-MallaínA, P. E.: Los hombres del Océano. Vida cotidiana de los tripulantes de las flotas de Indias. Siglo XVI, Sevilla, Diputación de Sevilla, 1992; ID.: El hombre frente al mar. Naufragios en la Carrera de Indias durante los siglos XVI y XVII, Sevilla, Universidad de Sevilla, 1996.

23 Thomas de Kempis: Comptentus mundi, Barcelona, Librería Católica Internacional, 1927, p. 21. Esta edición sigue la traducción de Fr. Luis de Granada, publicada en Sevilla en 1536.

24 Portichuelo de Rivadeneira, D.: Relación del viaje y sucesos que tuvo desde que salió de la ciudad de Lima hasta que llegó a estos reinos de España, Buenos Aires, Biblioteca Ibero-Americana, 1905, p. 67. 
prescriben ordenanzas y libros de navegación, se habría de vivir "cristianamente y en el temor de Dios", una norma que también solían vigilar los capellanes y religiosos presentes en la navegación. Un medio ideal de la salud espiritual de pasajeros y tripulantes, en una secuencia vital en continuo contacto con la muerte, fueron las prácticas sacramentales; entre las que destacan la confesión, la eucaristía, la unción de enfermos y la penitencia. Esta última, aparecía como uno de los remedios más eficaces frente a los habituales infortunios del viaje; incluso el lexicógrafo Sebastián de Covarrubias (1539-1613) dice que

así como el que en una tormenta ha perdido el navío tiene necesidad de asirse a alguna tabla para no ahogarse, así el que en la tormenta del pecado perdió la inocencia bautismal tiene necesidad del sacramento de la penitencia para no ahogarse en el profundo infierno ${ }^{25}$.

Los tratados náuticos, por ello, insisten en que nadie embarcase sin haber procurado estado de gracia, y que durante el trayecto oceánico se celebraran metódicamente los ritos religiosos pertinentes, de ahí que los barcos fuesen equipados con los ornamentos y libros litúrgicos necesarios. Había que evitar, pues, morir en pecado, algo factible en cualquier momento repentino en un piélago acuático que la mentalidad de la época equiparaba al infierno; el navío, pues, sería una especie de purgatorio, o sea, un abismo purificador, inhóspito y doloroso, provisional si se aprovechaba como ruta de conversión y perfección.

Los jesuitas portugueses en idénticos avatares, al igual que los demás, también desaconsejaban y secuestraban lecturas profanas del cariz de las exitosas ficciones caballerescas, los cuentos eróticos y sentimentales, la Fiametta de Bocaccio o los metros itálicos de Boscán y Garcilaso. Más de lo mismo encontramos en los tres meses de navegación entre Goa y Macao. En mayo de 1586, dos padres y un coadjutor embarcaron en la nao Nuestra Señora del Rosario con destino a China, senda en la que aquellos dos jóvenes sacerdotes cada día decían misa rogando a Dios que la lluvia, el viento y la navegación nunca les estorbara su ministerio y obligaciones. Excepto cuando estaban muy enfermos, siempre cantaban letanías a la Virgen a medio día y jamás cejaban en el auxilio espiritual de los pasajeros. Cada noche reunían en la cubierta a los mareantes y esclavos africanos del buque para enseñarles la doctrina del Altísimo y cantar con ellos oraciones. Tampoco escatimaron en el derroche de caridad ni en el cuidado de enfermos y necesitados, tanto de sus cuerpos como de sus almas; a cambio, todas las mañanas muy temprano, en voz alta y devota, convidaban a los presentes a alabar a Dios y a la Virgen ${ }^{26}$.

25 Covarrubias, S. DE: Tesoro de la lengua castellana o española (1611), Madrid, Castalia, 1995, p. 812. Sobre la religiosidad a bordo un buen trabajo es el de HernÁndez DíAz, C.: "Asistencia espiritual en las flotas de Indias”, en Torres, B. (ed.): Andalucía, América y el mar, La Rábida, Junta de Andalucía, 1991, pp. 271282; y los de SÁnchez Reyes, G.: "Zarpar bajo el cobijo divino. Prácticas religiosas en los viajes de la Carrera de Indias"; y Montero Recoder, C.: "Encarando a la muerte", ambos en Trejo, F. (coord.): La flota de la Nueva España 1630-1631, México, Instituto Nacional de Antropología e Historia, 2003, pp. 145-208 y 209244 , respectivamente.

26 Al respecto Loureiro, R. M.: "Livros e bibliotecas europeias no Oriente (século XVI)", Revista de Cultura, XXXII (1997), pp. 19-34; ID.: A Biblioteca de Diogo Couto, Lisboa, Instituto Cultural de Macau, 
Desde principios del siglo XVII aquellos jesuitas, antes de embarcar rumbo a Oriente, recibían normas de sus superiores con las que regular sus vidas y deberes en unas travesías oceánicas de, en total, más o menos un año de duración. Conforme los preceptos de los mandatarios de la Compañía, los ignacianos debían viajar en grupos de 10 ó 12. En concreto, las instrucciones dadas por el padre João Álvares, después de su visita a Portugal en 1610, como las de Francisco Vieira, visitador de la provincia de Japón en 1616, son una consecuencia de la experiencia en Asia de jóvenes sacerdotes, coadjutores y escolares. Dichas órdenes debían ser leídas a bordo en voz alta y varias veces mientras durase el viaje, a modo de sempiterno recordatorio de obligaciones cotidianas bien calibradas y capaces de asegurar la resistencia de los neófitos en retos semejantes; sobre todo no cejar en 4 reglas fundamentales: rezar con diligencia y continuamente, cuidar con esmero la salud, seguir instruyéndose en los métodos misionales que iban a ejercer y atender material y espiritualmente a pasajeros y tripulantes. Vieira, en las suyas, reta a los implicados con la entrega desinteresada de Francisco Javier, una guía arquetípica capaz de hacer de ellos otros apóstoles de Oriente; y apostilla que "era lo que se esperaba de nosotros y fue lo que nuestros predecesores siempre hicieron en estos viajes" 27 .

El responsable de cada grupo, un padre experimentado, era el encargado de asignar las tareas cotidianas al resto de la expedición; además, hacía de confesor general y de portavoz cuando hubieren de negociar con las autoridades del barco. En todo momento debía garantizar un clima propicio a bordo, resolviendo cualquier conflicto que surgiere entre sus correligionarios, pues, en tantas y exasperantes jornadas de trayecto, los altercados, por los más nimios motivos, eran moneda corriente. Con la misma porfía tenía que vigilar el estricto cumplimiento de los quehaceres previstos para los padres expedicionarios, ante todo la predicación y la confesión. Coadjutores y escolares, el cuidado de las provisiones, la cocina, la higiene -esencial medida preventiva-, la atención de los enfermeros y enseñanza de la doctrina a los marineros. Pero, aparte del estudio, el primer deber de unos y otros sería el ejercicio de su ministerio espiritual con la gente embarcada, cuyo fin, según Vieira, no era otro que "ganar almas para Dios y muchos amigos para la Compañía".

Mucho más rigurosa fue la organización de la vida religiosa de los jesuitas en los navíos y, a ser posible, la del resto de pasajeros y tripulantes. Conforme a lo preceptuado por los superiores, el progresivo incremento de la piedad de los allí presentes debía ser el objetivo prioritario. Así, al mediodía se reunirían en cubierta para entonar letanías, rezar el rosario, celebrar misas en pequeños grupos, excepto las generales de los días de fiesta; enseñar los rudimentos de la fe, leer en voz alta libros devotos o promover otros entretenimientos sin ofensa de Dios. Todo ello para animar el examen de conciencia y la confesión. Una vez se doblaba el Cabo de Buena Esperanza, es decir, transcurrido la mitad del viaje -unos 6 meses-, cuando ya todos estaban diezmados

1998, y Palomo, F.: “Corregir letras para unir espíritus. Los jesuitas y las cartas edificantes en el Portugal del siglo XVI", Cuadernos de Historia Moderna. Anejos, IV (2005), pp. 57-81.

27 Véase Brockey, L. M.: Journey to the East. The Jesuit Mission to China, 1579-1724, Harvard University Press, 2007. Sobre Brasil: SouZA, L. DE Mello e: Inferno Atlântico. Demonologia e colonização, séculos XVIXVIII, São Paulo, Companhia Das Letras, 2001; y ABreu, M.: Os caminhos dos livros, Campinas, Mercado de Letras, 2003. 
de tanto océano, la tarea primordial de aquellos religiosos consistiría en el consuelo y sosiego de violencias, ansiedades, miedos, angustias, melancolías, desesperaciones y otras dolencias corporales y anímicas propias de aquella funesta aventura. Y lo hacían como mejor creían y sabían: con oraciones, misas, confesiones, procesiones e imágenes. La invocación de los santos solía ser la norma frente a demasiado viento o la calma del mismo. João Álvares, ante estas afrentas a causa del pecado, apremia a "tener gran cuidado de mantener el barco en paz", porque entonces solían acontecer peleas por doquier, más entre la marinería, como las fatales discusiones entre capitanes y pilotos a la hora de resolver problemas técnicos de navegación en medio de fatales contratiempos.

\section{ESCARMIENTO DE CODICIA Y CURIOSIDAD}

En la mentalidad colectiva el mar era el dominio privilegiado de Satán y de las potencias infernales, un lugar de miedo y muerte, lleno de monstruos horribles y peces gigantes, unido al pecado y atractivo para el mal, al que es necesario exorcizar y rezarle cuando se enfurece ${ }^{28}$. En la expedición de Álvaro de Mendaña (1542-1595) por el sur del Pacífico, perdida un día en el océano y presa de una tormenta, los mareantes de la nao capitana comenzaron a hacer plegarias y oraciones y a echar al agua rosarios e imágenes sagradas, "como es costumbre de navegantes cuando se ven en peligro, como nosotros a esta hora estauamos, y fue Dios seruido" 29 . Esta percepción conecta con el tópico de la Antigüedad sobre los peligros de la navegación y el desafío a los dioses que suponía entregarse a la furia de las aguas y los vientos en una endeble embarcación. El navegante, un ambicioso venturero, se mueve por su egoísmo y en beneficio propio antes que el de la comunidad. El fin del héroe, según ensalzan Horacio y Virgilio, jamás debe ser su provecho individual sino el bien público, un objetivo que merece riesgos, esfuerzos, hazañas altruistas y, a cambio, recompensas. La aventura marítima, la perversa nave, corrompió la mítica Edad de Oro, una época, dice Tibulo, "sin igual, cuando la tierra no abría largas rutas, cuando el pino ahuecado no andaba desafiando los mares, ni el mercader se fiaba a los peligros por tierras ignoradas" 30 .

Los arbitristas españoles del siglo XVII, el tiempo de la decadencia hispánica, la Edad de Hierro, del mismo modo añoraban un pasado idealizado -que hacen coincidir con el reinado de los Reyes Católicos y, menos, con el de Carlos I- en el que hombres virtuosos, resueltos en sencillez, habilidad marcial y celo religioso, cumplían los designios celestiales. Pero, los espejismos de las Indias, los lances de descubrimientos y conquistas y unas riquezas logradas sin derroche de fuerza, terminaron arruinando las conciencias y las buenas costumbres del pueblo elegido de Dios. Aquellos proyectistas y reformadores no descansaban en el empeño de hallar la solución a la

28 De ninguna manera podemos prescindir de Delumeau, J.: El miedo en Occidente, Madrid, Taurus, 2002 , pp. 53-88.

29 Relación de Álvaro de Mendaña al Rey Don Felipe II, edición de C. Kelly, Madrid, Archivo IberoAmericano, 1965, p. 6.

30 AínsA, F.: "El viaje como trasgresión y descubrimiento. De la Edad de Oro a la vivencia de América", en PeÑate, J. (ed.): Relato de viaje y literaturas hispánicas, Madrid, Visor Libros, 2004, pp. 45-70. 
declinación del Reino, un cuerpo enfermo necesitado de una cura urgente, y aun de cauterio, que le devolviera la lozanía de antaño, cuando, a juicio de Lope de Deza (1546-1625)

esta Monarchía se terminava con sus mares y Pyrineos, no teniendo sus naturales a que divertirse ni a que aspirar a nuevas embarcaciones y esperanças, más que al beneficio de sus tierras y ganados, pescas y demás artificios y granjerías propias suyas ${ }^{31}$.

Pese a que en el Renacimiento se reafirma la experiencia oceánica frente al tópico negativo de la Antigüedad, la literatura de los siglos XVI y XVII, como los relatos de nuestros viajeros, aunque ellos no se apliquen el remedio, es pródiga en anatemas contra el mar, cuya vesania era el castigo providencial de la codicia y la soberbia del navegante. No en vano el ama de Don Quijote amonestaba a Sancho para que dejara de pretender ínsulas ni ínsulos y regresara a gobernar su casa y labrar sus predios. Incluso un osado viajero como el franciscano Laureano de la Cruz, que vuelve a España del Perú a fines del Seiscientos, clausura el relato de su vivencia marítima con el siguiente colofón:

Con esto nada de lo de acá les puede desvaneçer este heroyco movimiento, pues fuera locura buscar por medio de la muerte, gloria que se ha de goçar viviendo, y es esta resoluçion en los de nuestros tiempo con muchos desengaños... ${ }^{32}$.

Este topos antiguo lo heredan los escritores del Siglo de Oro, atizadores de las denuncias del afán de lucro de los mareantes, hombres corrompidos por unos tesoros, la mayoría de las veces, huidizos y fraudulentos ${ }^{33}$. Cristóbal Suárez de Figueroa (1571c.1644) resume una opinión común entre los intelectuales de su tiempo, situando la causa y principio de esta añagaza marítima, como Homero y Horacio, en "querer los hombres salir de pobreza por fuego y agua, aventurando entre la esperanza del ganar y el medio de los peligros". Poco condescendiente con los pobladores europeos de las Indias, sus "sabandijas antárticas y equinocciales", en su obra El pasajero (1617), sin disimular hostilidad hacia ellos, pone en boca del Doctor:

No deben los que navegan contarse con los vivos ni con los muertos; mas como gente que tiene su vida puesta en balanza. Sólo el esperar les conserva un cierto rastro y sombra de la vida, siendo él solo en tanto peligro su aliento y su vivir. ¿Hay trance tan espantoso como es estar los que navegan no más lejos de la muerte de cuanto tiene

\footnotetext{
31 Deza, L. DE: Gobierno político de agricultura (1618), edición de A. García Sanz, Madrid, Instituto de Cooperación Iberoamericana, 1991, p. 65. Sobre el tema: GARcíA-BAQuero, A.: "Del deslumbramiento al cálculo. La reverberación de América en la conciencia económica española”, en Musset, A. y CALvo, T. (eds.): Des Indes Occidentales à l'Amerique latine, París, ENS Editions, 1997, vol. 2, pp. 423-437.

32 Cruz, L. de la: Descripción de los Reynos del Perú con particular noticia de lo hecho por los franciscanos, Lima, Pontificia Universidad Católica del Perú, 1999, p. 440. Se trata de un manuscrito, de la Biblioteca Nacional de Madrid, inédito hasta la publicación de dicha obra.

33 Véase Brioso Santos, H.: América en la prosa literaria española de los siglos XVI y XVII, Huelva, Diputación de Huelva, 1999; DAVIS, E. B.: "Iglesia, mar y Casa Real: Imaginario de la odisea en la épica del Siglo de Oro", en García Castañeda, S.: Literatura de viajes. El Viejo Mundo y el Nuevo, Madrid, Castalia, 1999, pp. 75-82; ID.: "La promesa del náufrago: el motivo marinero del ex-voto, de Garcilaso a Quevedo", en Schwart, L.: Studies in honor of James O. Crosby, Newark, Juan de la Cuesta, 2004, pp. 111-125.
} 
de grueso la tabla del navío, casi como desesperados de todo remedio? Grande audacia fue (dice Plinio) querer probar el mar; ni fue sin injuria de los hombres la temeridad del que tal arte inventó ${ }^{34}$.

Un mar aterrador e impredecible que, en La tempestad de Shakespeare, desvía a tierra los anhelos de Gonzalo, quien en medio de la tormenta clama:

Diera yo ahora mil estadios del mar por un acre de tierra baldía, o páramo extenso, o erial espinoso. ¡Tanto da! ¡Hágase la voluntad de los cielos! ¡Dios, me habría gustado morir de muerte seca! ${ }^{35}$.

No hubo infortunio o desaliento, sin embargo, que convenciera a los religiosos de aligerar sus equipajes de libros, un avituallamiento poco adecuado ni aconsejable en el sempiterno, tortuoso y, no pocas veces, apocalíptico viaje de la infernal mar océana o por los tan distantes y ásperos caminos de semejantes mundos nuevos ${ }^{36}$. Sólo la pasión y un imperioso menester subyacen en esta decisión de un matalotaje abultado en demasía, que ahogaba más si cabe el angosto buque de naos y galeones, que mil quebraderos de cabeza daría a más de uno. Mas venía a compensar el piélago de tedios, pesares y temores, del cuerpo y del alma, que habrían de sufrir en aquella desquiciada arcadia de los infiernos atlánticos. Pero ¿cuántos no sucumbieron a las aguas y rudezas de tierras extrañas?, como Jonás en las fauces de la ballena; aunque gracias a Dios daba el clero cuando el mar engullía, cual castigo providencial, el vicio y la mala hechura de historias ficticias y deshonestas, en nada edificantes y siempre reñidas con las virtudes que debía engalanar la piedad del buen cristiano.

No por casualidad los visitadores de la Inquisición, en caso de encontrar en las naves dicha poética licenciosa, la condenaban a perecer en el salado y desconcertante líquido elemento, en las húmedas calígines del demonio. Así sucedió en la nao Santa Catalina, llegada desde Sevilla a Veracruz en 1585, en la que el comisario del Santo Oficio de turno halló a dos pasajeros que llevaban dos oratorios espirituales, que “cuando les dijeron que estaban prohibidos los echaron al mar". En el mismo puerto, también sirvieron de alimento a los peces "dos pares de horas que el comisario mandó echar al agua" en 1595 en el navío "San Rafael" 37.

El incomodo de la tierra lo soportó Fr. Diego de Ocaña, un jerónimo manchego que profesó en el monasterio de Guadalupe en 1588. Éste decidió pasar al Nuevo Mundo, acompañado del asturiano Fr. Martín de Posada, con el propósito de fomentar la de-

\footnotetext{
34 SuÁrez de Figueroa, C.: El pasajero, Madrid, PPU, 1998, p. 338.

35 Shakespeare, W.: La tempestad, Madrid, Cátedra, 1997, p. 60.

36 Remito a mi libro New World Literacy. Writing and Culture Across the Atlantic 1500-1700, Lewisburg, Bucknell University Press, 2011; a Howsam, L. y Raven, J. (eds.): Books between Europe and the Americas: Connections and Communities, Houndmills, Palgrave Macmillan, 2011; y Rueda Ramírez, P., Negocio e intercambio cultural: el comercio de libros con América en la Carrera de Indias (siglo XVII), Sevilla, Universidad de Sevilla, 2005.

37 Ambas citas en las actas de visitas de navíos recopiladas por Fernández del CASTILlo, F., op. cit. (nota 10), p. 435. Sobre este tema: GonzÁlez Sánchez, C. A. y Rueda Ramírez, P. J.: "Con recato y sin estruendo. Puertos atlánticos y visita inquisitorial de navíos", Annali della Scuola Normale Superiore di Pisa, serie 5a, $1 / 2$ (2009), pp. 473-506.
} 
voción a la Virgen de Guadalupe. Allí, dondequiera que estuviere, dice "iba notando todo lo que había", apuntes con los que redactó una relación de sus andanzas por tierras americanas entre 1599 y 1605, tal vez en Lima, aunque moriría en Nueva España en 1608. Yendo en 1599 de Portobelo a Panamá, describe la industria empleada en el transporte de unos libros:

Alquilamos nueve mulas, las cuales nos costaron veinte pesos de a ocho reales el peso cada una, por solas dieciocho leguas que hay desde Portobelo a Panamá, las cinco mulas para llevar los trecientos cuerpos de libros de la historia de nuestra señora ${ }^{38}$.

Esos impresos fueron la divisa de su pretendida promoción de la veneración guadalupana, un culto cuya difusión también apoyó el rey Felipe III amparando, como consta en una carta suya, el viaje a Indias de los padres de los monasterios de Guadalupe, Valencia y Posada, a quienes facilitó cuantos manuales de estudio y "volúmenes de libros de la historia de la dicha imagen de Guadalupe y fundación de su casa" quisieren ${ }^{39}$.

De peor aflicción, de melancólica nostalgia sobre todo, fue presa el dominico Fr. Tomás de la Torre, un buen escritor versado en teología. Según se dijo atrás, entre Campeche y Tabasco hubo de navegar, con su grupo de correligionarios, en viejas barcazas por cursos de agua enrevesados y peligrosos, impedimento que les obligó varias veces a reacomodar en los pequeños buques el matalotaje de la expedición, señaladamente, cuenta, "muchos libros -20 cajas- nuestros y del señor obispo", Bartolomé de las Casas; pero la carga, demasiado pesada, y una tormenta atroz en la laguna de Términos hicieron naufragar al batel, dando al traste con una preciada vitualla indispensable en el estudio y la oración. Relata el fraile, sin ahorrar en tristezas y lamentaciones, que murieron 32 personas, nueve de ellas religiosos; varias porque se echaron al agua para salvar los libros, unos instrumentos casi imposibles de reponer en aquellas tierras alejadas del Viejo Continente ${ }^{40}$. Si bien, quiso la fortuna, y el arrojo y la osadía de quienes no cejaron en el rescate, que recuperaran 10 ó 12 de las cajas hundidas, "enterradas en cieno en las orillas de aquella laguna". Tal era el deterioro de los impresos que pensaron no poderlos salvar; incluso uno de los frailes, Domingo de Azcona, los llevó en canoa a un pueblo, distante seis leguas, para lavarlos con agua dulce. Fr. Tomás, entre amargura y un júbilo subrepticio, continúa el relato:

Padecimos aquí grandes trabajos y soles y calores, en curar los libros y lavarlos, deslodarlos, despegarlos y si todos no viniéramos, nunca se remediara, y así con trabajo de todos se aprovecharon los más, especialmente los que tenían encuadernaciones de pergamino que se les pudieron quitar; pero quedaron con pestífero olor que jamás se les quitó. Después hemos visto que sin tocarlos se van ellos pudriendo y gastando; en

38 OCAÑA, D. DE: Un viaje fascinante por la América hispana del siglo XVI, edición. de A. Álvarez, Madrid, Studium Ediciones, 1969, p. 21.Una copia de la relación la mandó al monasterio extremeño, aunque hoy día se encuentra, inédita, en la Biblioteca Universitaria de Oviedo.

39 Ibidem, p. 22. El libro, dos veces, aludido podría ser la Historia de Nuestra Señora de Guadalupe del padre Fr. Gabriel de Talavera, publicada en Toledo en 1597. En 1599 era la única historia editada de dicha advocación.

40 Torre, T. DE LA, op.cit. (nota 7), pp. 287-293. 
esto de los libros entendimos con más trabajo que nadie puede pensar desde el viernes que llegamos allí hasta el miércoles de esa otra semana ${ }^{41}$.

A los maltrechos libros, claro está, se les dispensó un remedio y mimo de singular consideración, incluso mayor y más esmerado que el dado a los difuntos en la catástrofe; porque éstos ya estaban muertos, y aquéllos, aunque agonizantes, aún vivían. Sin ellos, la vida allí hubiera sido diferente. La oración, el estudio, el aburrimiento, lo insano del entorno y demás obligaciones misionales requerían, sin alternativa imaginable, el auxilio de unos textos colmados de mil virtudes y cualidades portentosas. No sin ingenua sinceridad, el autor de la narración apostilla que "pasaron estos padres tantos trabajos por buscar los cuerpos de los difuntos y los libros que no se pueden contar".

Similar es el suceso acaecido a Francisco Samaniego Tuesta (1598-1645), que, presto a tomar posesión de su reciente nombramiento, en 1644, como Fiscal de Manila, apresuró el viaje desde Acapulco hasta Filipinas. Navegando en el interior del Archipiélago del Pacífico, el 21 de noviembre, un huracán doblegó la embarcación en la que viajaba, provocando el extravío de, según él, muchas "chucherias que traia de mi gusto y lo que mas es 24 caxones de libros". Pero todas sus lamentaciones y quejas doloridas las acaparó la pérdida de los libros, un acontecimiento aflictivo, inesperado y fortuito que le hizo escribir y sentenciar que "con la perdida de mis libros se me acabaron todas mis curiosidades" ${ }^{42}$. Tan feroz meteoro y la desaparición de los textos, relata, fueron el castigo de Dios a su curiosidad, cualidad entonces considerada por los moralistas un vicio propio de la vanidad inherente al querer saber sobrado, el fruto a su vez de una ociosidad impía y malsana, de no gastar el tiempo en devota y honrosa ocupación ${ }^{43}$. Para unos y otros, en suma, tamaños desastres ponían fin a unos repertorios gráficos, sin alternativas, cuya reunión requería larga espera, entusiasmo, prolongados y difíciles transportes y algo más que dinero y paciencia. Todo ello a causa de los deficientes, espaciados y lentos, suministros peninsulares. Un coetáneo, el cura y escritor malagueño Miguel Cabello Valboa (1535-1608), afincado en el Perú de mediados del siglo XVI, en el prólogo al lector de su Miscelánea antártica hace eco de las cuitas - por experimentarlas a la hora de componer su poliantea- que en Indias padecían bibliófilos y hombres de letras hasta la consecución de materia prima impresa:

Pues qué te podré decir de la carestía con que acaudalaba una autoridad de las muchas que han sido menester, certifícate que ha habido alguna que, por alcanzarla, se han caminado en idas y venidas más de cien días, y otras que se han adquirido con la importunación de muchas cartas colmadas de plegarias y ruegos. Porque aquí no tenemos caudal ni aparejo para tener librerías, y los que las tienen están en las ciudades,

41 Ibidem.

42 Esta breve relación está inserta en la Carta de Francisco de Samaniego Tuesta, fiscal de Manila, a D. Juan Díez de la Calle, oficial mayor de la secretaría de Nueva España, en que cuenta las peripecias de su viaje desde el puerto de Acapulco, mandándole adjunto una relación de lo más memorable de las islas Filipinas. Archivo Histórico Nacional (AHN), Diversos, 27, doc.15.

43 Véase mi Atlantes de papel. Adoctrinamiento, creación y tipografía en la Monarquía Hispánica de los siglos XVI y XVII, Barcelona, Ediciones Rubeo, 2008, especialmente las páginas 103 y ss. 
hame sido grandemente dificultoso, recopilar lo poco y mal limado que en este libro hallarás ${ }^{44}$.

No va más de momento, ni requiere este discurso de mayores conclusiones que las que se han ido barajando a lo largo de sus páginas; que, en cualquier caso, el avance del estudio y la reflexión traerán mejor calibradas en el momento oportuno ${ }^{45}$.

\footnotetext{
44 Cabello Valboa, M.: Miscelánea antártica, edic. de L. E. Valcárcel, Lima, Universidad Nacional Mayor de San Marcos, 1951, p. 7.

45 No podía terminar sin citar una obra de gran interés para las cuestiones abordadas, aunque discutible en algunas de sus propuestas, me refiero al libro de Schwartz, S. B.: All Can Be Saved. Religious Tolerance and Salvation in the Iberian World, New Haven, Yale University Press, 2008. También, Kaplan, B. J.: Divided by Faith. Religious Conflict and the Practice of Toleration in Early Modern Europe, Cambridge, Harvard University Press, 2007.
} 